\title{
The Development of Mandarin Hanzi Instructional Videos to Increase Writing Skills
}

\author{
Urip Zaenal Fanani \\ Universitas Negeri Surabaya \\ Surabaya, Indonesia \\ zaenalfanani@unesa.ac.id
}

\author{
Rendy Aditya \\ Universitas Negeri Surabaya \\ Surabaya, Indonesia \\ Aditya_frenz11@yahoo.com
}

\author{
Dwi Didik Santoso \\ Universitas Negeri Surabaya \\ Surabaya, Indonesia \\ didiksantoso@unesa.ac.id
}

\begin{abstract}
As Mandarin learners, understanding Hanzi is difficult because there are rules in writing it. Therefore, in order to facilitate learners in getting materials on $\mathrm{Hanzi}$ writing and to attract learners' interests in Hanzi, a Hanzi writing instructional videos are made. The Hanzi writing instructional videos are created through setting the purposes, designing the Hanzi writing instructional videos, collecting appropriate materials, and creating the videos. University students give positive responses through the use of Hanzi writing instructional videos, however, from the results of satisfaction, the second video gets more satisfaction value than the first video.
\end{abstract}

Keywords-Instructional Video; Hanzi; Writing

\section{INTRODUCTION}

In line with the advance of technology, learning Mandarin has also been growing advanced. It can be seen from many videos about learning Mandarin which are uploaded on YouTube. This condition gives positive impacts for Mandarin Educators in which they compete to make Mandarin instructional videos so that it can be beneficial for those who want to learn Mandarin, including university students.

Mandarin instructional videos, including learning about Hanzi to increase writing skills are quite attractive since there are millions viewers who watch it. Therefore, Mandarin instructional videos are made in order to appeal Mandarin learners. By using instructional videos, it can motivate university students and facilitate understanding as well as memory in the learning process [1] so that it can be concluded that instructional videos, including about learning Hanzi writing, can facilitate university students to understand Mandarin language.

For the new students, batch 2019, who never learn about Mandarin language in secondary schools, Hanzi writing instructional videos are really awaited since it can give them insight to the Hanzi writing. Hamalik in Arsyad [2] states that the use of instructional media at the learning orientation stage will be very effective in the learning process.

From the explanation above, the research questions in this study are:

1) How is the development of Mandarin Hanzi instructional videos to increase Mandarin writing skills?

2) How are university students' responses toward the development of Mandarin Hanzi Instructional Videos to increase Mandarin writing skills?

Furthermore, the benefit of this study for educators is that being able to innovate in learning Hanzi writing so that the learning process is attractive, and university students will easily catch the materials. While the benefit for university students is that they can understand Hanzi writing so that they are expected to be interested in Hanzi. Then, for the next research, since the instructional videos which are used in this research is to teach basic Hanzi, hence, for other researchers, it is expected that the finding of this study will be beneficial and can be one of the sources to make Hanzi instructional videos for the intermediate and/or advanced level.

Moreover, the previous study which relates to the present study is titled "The Influence of the Use of Jeopardy Game Media on Basic Hanzi Writing Skills in Mandarin Language Class X Graders of SMA Negeri 1 Puri Mojokerto Academic Year 2015/2016” by Dewi [3]. In her conclusion, Dewi states that by using Jeopardy games, students' ability in basic Mandarin Hanzi writing is increasing. Another previous study that relates to the present study by Ulfa [4]. In her research, she concludes that students, who are taught by using greeting instructional video, get better results in their Japanese speaking ability than students who are taught by using pictures.

From those two relevant previous studies, the media which are used in the previous studies are different from the media which are used in the present study. The previous study used Jeopardy games and Greeting instructional video, while the present study uses instructional video to increase Hanzi 
writing skills. Hence, the present study is different from the previous study.

\section{A. Hanzi Writing}

Hanzi Writing is one of important skills in Mandarin language since letters - 汉字 Hànzı̀ — in Mandarin language is different from letters in Indonesian language. Akhadiah [5] states that the usage and written letters are very important in writing. The cause of mistakes in writing 汉字 Hànzì is the shapes of the letters which are complicated. Besides, it also has to match the sketch order. 汉字 Hànzì is Mandarin characters which are formally simplified by the government of People's Republic of China in order to improve literacy. Because of the complicated and unique writing, it requires practicing continuously in order to be able to memorize it. According to 黄(2005:163), 汉字 Hànzì is a symbol of written language and the most important communication tool. 汉字 Hànzì characters existed around 3000 years ago and has undergone several changes in order to make it simple as today's characters.

In writing Hanzi, Mandarin learners are expected to be able to write Hanzi based on the rules of the writing. Besides, in writing Hanzi, of course, there is a sequence of writing. Sketch is the most basic component in writing 汉字 Hànzì/Chinese Characters. Hence, sketch will usually be one of basic materials in Mandarin language for University students who has just learning it. The order of writing refers to the way to write in sequence [6].

\section{B. How to Develop Video-Based Multimedia}

Computer-based multimedia and interactive videos have stages in the development. Usman [7] states that there are several things that must be considered in choosing media, those are: the learning objectives, efficiency, students' condition, the availability of hardware and software, technical quality, and the costs. Besides, in developing instructional media, there are several factors that must be concerned, those are: funds, facilities, and available equipment. In addition, there are several stages in developing computer-based multimedia and interactive videos, those are: making concepts, designing, selecting materials, collecting materials, and creating materials. It will be explained further as follows.

Making concepts is the first stage to develop computerbased multimedia and interactive videos. A concept is an idea to determine purposes and the users of the program, in this case, university students. Besides, this also determines the kinds of presentation application, interactive, and so on. The purpose of application is entertaining, training, and learning. Next, designing is the second stage to develop computer-based multimedia and interactive videos. Designing is the stage of making specifications regarding to architecture program, style, appearance, and required materials for the program.

Collecting materials is the third stage to develop computerbased multimedia and interactive videos. Collecting materials must be based on the needs. Moreover, this stage can be done parallel to the assembly stage or linear stage. Furthermore, creating materials is the fourth stage of developing computer- based multimedia and interactive videos. The process involved people who are capable of utilizing various types of software. The development of multimedia application is based on storyboard and navigation structures which come from the designing stage [8].

\section{MethodS}

This research is categorized as a type of research and development. According to Borg \& Gall [9], "Educational Research and Development (RnD) is a process used to develop and validate educational products". Nana Syaodih [10] also states that research and development is a process for developing a new product or perfecting an existing product which can be accounted for. Through this research and development, the researchers try to develop products which are appropriate and effective to be used in learning. Products which are developed in this study are computer-based multimedia and interactive videos about Hanzi writing. This research uses a development model proposed by Borg and Gall [11] that consists of ten stages, however, in this research, the researchers simplify and limit the stages into four stages. This is based on the opinions of Borg and Gall in Emzir [12] which suggests that research which is limited into a small scale, include the possibility to limit the steps of research. Hence, the steps in developing instructional video for Hanzi writing are illustrated as follows.

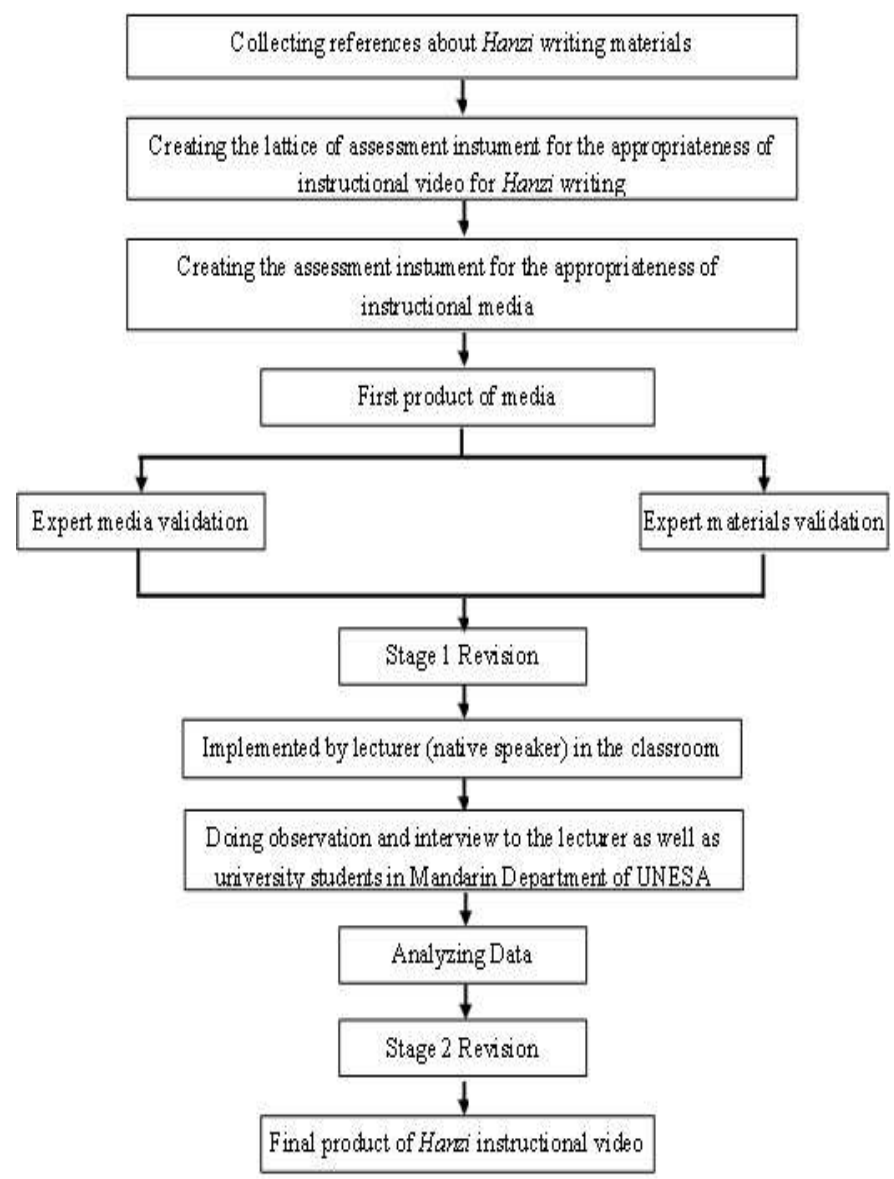

Picture 1.Stages of Developing Hanzi Instructional Vileo 
Furthermore, the research instrument is in the form of validation sheets from material experts and media experts, observation sheets, and interview guidelines. Material expert validation sheets are used to find out how deep the delivered materials and its relevance to the expected competencies. Media expert validation sheets are used to determine the appropriateness of the media to be used in learning. Observation sheets are used to know the use of the media in the teaching and learning process. Interview guidelines are used to find out responses, comments, and suggestions from lecturers and students after using instructional media.

\section{RESULTS AND DISCUSSION}

\section{A. The Development of Mandarin Hanzi Instructional Video to Improve Writing Skills}

In creating the development of instructional video for Hanzi writing, the first thing to do is determining the purpose and the users of the instructional videos. The purpose of creating this instructional video is to make students easier to understand the materials taught by the lecturer. Besides, by creating the instructional videos, it can attract university students' interests in learning Hanzi. Nonetheless, in order to achieve those two purposes, Hanzi instructional videos are created. After that, it is continued to design video-based multimedia by determining the duration of time and materials which will be taught. In this case, the duration of Hanzi instructional videos is limited to a minimum of five minutes and a maximum of ten minutes with consideration that if the duration is less than five minutes, the materials cannot be completely delivered. In contrast, if the duration is more than ten minutes, it takes much time for uploading in YouTube because the internet connection is not good enough. As a result, students are be able to determine how long the video takes time based on the ideal time mentioned above. Next, collecting Hanzi materials-basic Hanzi with few sketches. It is because the students have just known the Hanzi characters. The last stage is creating or producing. The process of creating the instructional video is evaluated from the first until the last, either the materials or the technique to create it. In this stage, students not only comprehend the material, but also they can practically understand how to use Hanzi in sentences.

\section{B. University Students' Responses Toward the Development of Mandarin Hanzi Instructional Videos to Increase Writing Skills}

In order to know university students' responses-the newest university students batch 2019 toward learning Hanzi writing - there are two videos which are used in this study. The duration of the first video is 9 minutes 31 seconds, while the duration of the second video is 6 minutes 2 seconds. In this case, both videos have been uploaded to YouTube. The links stated as follows:

Link for the first video is

https://www.youtube.com/watch?v=BAKcMQqww8E\&t=23s

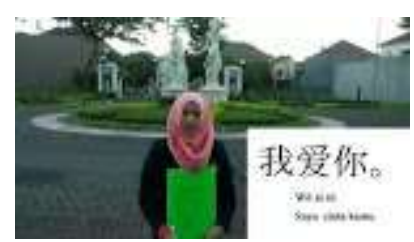

While link for the second video is https://www.youtube.com/watch?v=7TC0ARNZgMY

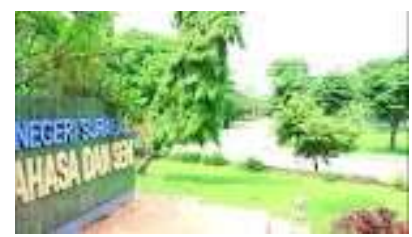

To know university students batch 2019's responses toward the two instructional videos, the data was collected on Friday, August $23^{\text {rd }}, 2019$ in T8.01.10 building at the State University of Surabaya, Lidah Wetan. Based on the data that have been gotten, university students' responses are positive, and they appreciate the two instructional videos because it makes them become more competent. The amount of 37 respondents give positive responses toward the second video rather than the first one based on its content and technique. The first video is lack of explanation in grammatical, fluency, and the appropriate intonation. In this case, the value of the second video is higher than the value of the first video.

\section{CONCLUSION}

Developing Hanzi instructional video is done through four stages those are determining the purposes, designing Hanzi instructional videos, collecting materials, and creating. Then, in order to know the responses from university students batch 2019 in Mandarin department toward learning Hanzi, two different videos are used. From the data, university students batch 2019 give positive responses for the two videos. Nevertheless, from the results of satisfaction, the second video gets higher value of satisfaction than the first video.

\section{REFERENCES}

[1] E. Rima Wati, Ragam Media Pembelajaran. Jakarta: Kata Pena, 2016, pp.1.

[2] A. Azhar. Media Pembelajaran. Jakarta: Raja Grafindo Persada, 2016.

[3] S. Puspita Dewi, "Pengaruh Penggunaan Media Permainan Jeopardy Terhadap Keterampilan Menulis Hanzi Dasar Bahasa Mandarin Siswa Kelas X Bahasa SMA Negeri 1 Puri Mojokerto Tahun Aajaran 2015/2016". Unesa: skripsi tidak diterbitkan, 2016.

[4] M. Ulfa. "Pengaruh Penggunaan Video Pembelajaran Salam Sapaan Bahasa Jepang Terhadap Keterampilan Berbicara Siswa Kelas X SMAN I Bangil Tahun Ajaran 2009/2010". Surabaya: skripsi tidak diterbitkan, 2010 .

[5] Alkhadiah, Sabarti, dkk, Pembinaan Kemampuan Menulis Bahasa Indonesia. Jakarta: Erlangga, 1988, pp. 180.

[6] Suparto, Penulisan Aksara Mandarin Yang Baik dan Benar. Jakarta: Puspa Swara, 2003, pp. 43.

[7] M. Usman, M. Basyiruddin, Asnawir, Media Pembelajaran. Ciputat: Delia Citra Utama, 2002. pp. 15

[8] E. Rima Wati, Ragam Media Pembelajaran. Jakarta: Kata Pena, 2016, pp.141.

[9] W. R. Borg \& M.D. Gall. Educational Research: An Introduction, Fifth Edition. $5^{\text {th }}$ ed. New York: Longman, 1983, pp. 772.

[10] N. Syaodih Sukmanta, Metode Penelitian Tindakan. Bandung: Remaja Rosda Karya, pp. 164

[11] W. R. Borg \& M.D. Gall. Educational Research: An Introduction, Fifth Edition. $5^{\text {th }}$ ed. New York: Longman, 1983, pp. 775.

[12] Emzir, Metodologi Penelitian Pendidikan. Depok: PT. Raja Grafindo Persada, 2013, pp. 271. 